\title{
Respiratory Muscle In Post-Polio Syndrome: Highlights
}

\author{
Marco Orsini*1, Mauricio De Sant Anna ${ }^{2}$, Carlos Henrique Melo Reis ${ }^{3}$, Ricardo Martello ${ }^{4}$, Eduardo Trajano ${ }^{5}$, \\ Carlos Eduardo Cardoso ${ }^{6}$, Marcos RG de Feritas ${ }^{7}$ and Acary SB Oliveira ${ }^{8}$
}

${ }^{1}$ Masters Program in Science Applied Health - Vassouras University and Masters Program in Local Devolopment - Unisuam. CASF Ramon Freitas - Neurology Service- Nova Iguaçu- RJ-Brazil

${ }^{2}$ IFRJ. Federal Institute of Rio de Janeiro - Brazil. Physical Therapy Service

${ }^{3}$ Rio de Janeiro Federal University - UFRJ, Brazil

${ }^{4}$ Masters Program in Science Applied Health - Vassouras University- Brazil

${ }^{5}$ Masters Program in Science Applied Health - Vassouras University

${ }^{6}$ Masters Program in Science Applied Health - Vassouras University

${ }^{7}$ Federal University of Rio de Janeiro - Neurology Service - UFRJ

${ }^{8}$ São Paulo Federal University - Unifesp - Neurology Service - Brazil

Received: 睯: November 23, 2018; Published: 偠: November 30, 2018

*Corresponding author: Marco Orsini, Department of Neurology, Fluminense Federal University, Rio De Janeiro, Brazil

\section{Short Communication}

The main function of the respiratory muscles is the movement of the thoracic wall, thus exerting ventilation, and the increase in the work of this muscle is directly proportional to the intensity of the activity performed De Troyer et al. [1-3]. During basal respiration, the slow-twitch fibers are used, while the fast-twitch fibers are recruited because of increased heart rate Sinderby et al. [4]. The diaphragm moves caudal approximately 1 to $3 \mathrm{~cm}$. Under conditions of ventilatory effort this incursion can reach up to $10 \mathrm{~cm}$. For an adequate work performed by the ventilatory muscles, approximately 1 to $3 \%$ of the oxygen consumption (V02) Kress et al. [5,6]. Several clinical conditions can modify this process, leading to a greater demand for breathing muscles, such as obesity Sant Anna Junior M et al. [7], chronic obstructive pulmonary disease, heart failure, amyotrophic lateral sclerosis among others. We could not fail to mention that post-poliomyelitis syndrome (PPS) can affect the ventilatory muscles, and just as in the peripheral musculature the muscles of respiration are affected in a non-symmetrical way triggered several forms of alteration Laghi et al. [6]. Due to the asymmetric distribution of muscle weakness produced by PPS, there is no rule regarding alteration in respiratory muscles, which can occur both in the inspiratory and in the expiratory musculature Orisini et al. [8,9]. demonstrated that in their study, patients with PPS when compared to a control group did not present differences regarding lung function, strength and resistance of the respiratory muscles in resting condition, but when submitted to a higher ventilatory stress through the test of maximum voluntary ventilation observed a significant reduction in inspiratory muscle strength. It should be noted that in exercise the peripheral musculature competes for blood flow to the respiratory muscles Dempsey et al. [3]. For this reason to reduce the possibility of overuse, perhaps the performance of a low intensity training specifically targeted to the ventilatory muscles and that has already proved efficient in other populations Ferreira EVM et al. [5] could improve exercise tolerance and quality of life in patients with PPS, but the literature is still unclear regarding respiratory muscle training for this population and variables such as frequency, intensity, duration and load deserve further clarification. There is a need for the respiratory muscle function of patients with PPS to be monitored and today the simplest and non-invasive techniques are: esophageal catheter and diaphragmatic electrical stimulation, which are invasive techniques described in the literature but less commonly used in clinical practice, electromyography (needle or surface electrode), and the most commonly used manuvacuometry (analog and digital), ventilometry and ultrasonography Caruso P et al. [10]. The study by Klefbeck et al. [11] described elegantly, despite the small sample (10 subjects) with signs of hypoventilation and indication of invasive ventilatory support, who underwent respiratory muscle training daily for a period of ten weeks. The outcomes evaluated were spirometry, respiratory muscle strength and endurance and ability to perform daily activities. Improvement in respiratory muscle strength and endurance was observed, as well as greater tolerance for recruitment of respiratory muscles, as 
assessed by the subjective sensation of effort scale. It has also been reported an improvement in the performance of daily activities, and the authors concluded that training of respiratory muscles was beneficial for patients with post-polio syndrome who already have indication of non-invasive ventilation.

\section{Final Considerations}

The process of evaluation of respiratory muscles in patients with post-polio syndrome is well described in the literature. However, the benefits of respiratory muscle training for this population are not yet well established, as are the variables necessary for prescription, such as intensity, frequency, duration and workload. However, it is important to emphasize that it is a promising field of investigation.

\section{References}

1. De Troyer A, Estenne M Estenne (1988) Functional anatomy of the respiratory muscles. Clin Chest Med 9(2): 175-193.

2. De Troyer A, Leeper JB, Mc Kenzie DK, Gandevia SC (1997) Neural drive to the diaphragm in patients with severe COPD. Am J Respir Crit Care Med 155(4): 1335-1340.

3. Dempsey JA, Romer L, Rodman J, Miller J, Smith C (2006) Consequences of exercise-induced respiratory muscle work. Respir Physiol Neurobiol 151(2): 242-250.

ISSN: 2574-1241

DOI: 10.26717/BJSTR.2018.11.002127

Marco Orsini. Biomed J Sci \& Tech Res

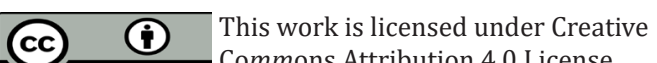

Submission Link: https://biomedres.us/submit-manuscript.php
4. Sinderby C, Beck J, Spahija J, Weinberg J, Grassino A, et al. (1998) Voluntary activation of the human diaphragm in health and disease. J Appl Physiol 85(6): 2146-2158.

5. Kress JP, Pohlman AS, Alverdy J, Hall JB (1999) The impact of morbid obesity on oxygen cost of breathing VO2 (RESP) at rest. Am J Respir Crit Care Med 160(3): 883-886.

6. Laghi F, Tobin MJ (2003) Disorders of the respiratory muscles. Am J Respir Crit Care Med 168(1): 10-48.

7. Sant Anna Junior M, Carneiro JRI, Carvalhal RF, Torres DFM, Cruz GG, et al. (2015) Cardiovascular Autonomic Dysfunction in Patients with Morbid Obesity. Arq Bras Cardiol 105(6): 580-587.

8. Orsini M, Lopes AJ, Guimarães FS, Freitas MR, Nascimento OJ, et al. (2016) Currents issues in cardiorespiratory care of patients with postpolio syndrome. Arq Neuropsiquiatr 74(7): 574-579.

9. Ferreira EVM (2015) Respiratory muscles: myths and secrets. J Bras Pneumol 41(2): 107-109.

10. Caruso P, Albuquerque ALP, Santana PV, Cardenas LZ, Ferreira JG, et al. (2015) Diagnostic methods to assess inspiratory and expiratory muscle strength. J Bras Pneumol 41(2): 110-123.

11. Klefbeck B, Lagerstrand L, Mattsson E (2000) Inspiratory muscle training in patients with prior polio who use part-time assisted ventilation. Archives of Physical Medicine \& Rehabilitation 81(8): 1065-1071.

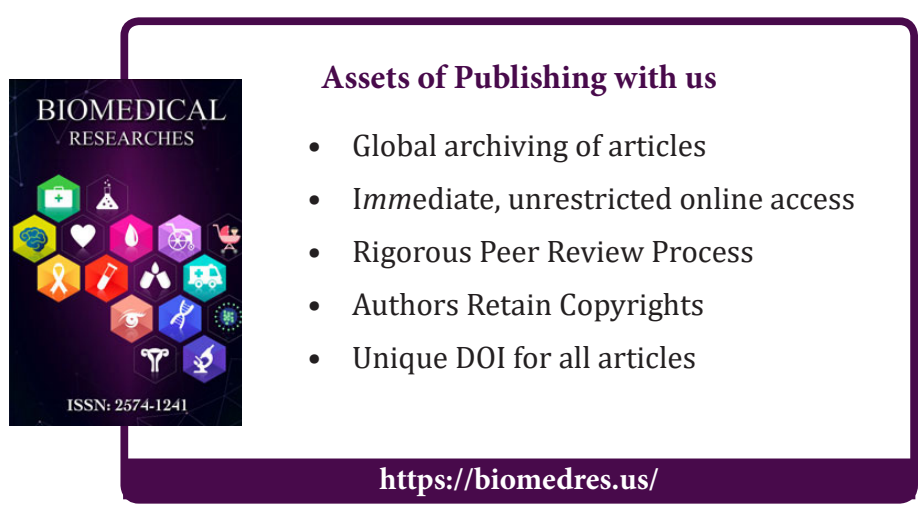

